\title{
„POLITYKA KRZYWDY” PIS
}

\section{Streszczenie}

W poszukiwaniu odpowiedzi na pytanie dlaczego partia rządząca w Polsce (PiS) utrzymuje tak silne poparcie, uciekamy się do argumentów z pogranicza socjologii, analizy dyskursu, psychologii społecznej i filozofii kultury, utrzymując, że PiS konsekwentnie prowadzi populistyczną politykę, która opiera się na budowaniu silnych antagonizmów społecznych i podsycaniu krzywdy. Pojęcie krzywdy ma wyjątkową i niespotykaną moc, która działa na uczucia i wyobraźnię ludzi. To sprawia, że jej przywoływanie jest szczególnie poręcznym narzędziem zarządzania sumieniami i przekonaniami obywateli. W tym duchu rozważamy, w jaki sposób krzywda i związane z nią pojęcia (resentyment) zaprzęgnięte są w politykę populistyczną, jak dyskurs krzywdy uobecnia się w najnowszej polityce historycznej kraju, i jak może przysparzać niektórym grupom społecznym ,perwersyjnej” satysfakcji. W tej połowicznie uświadomionej taktyce, którą określamy jako „,politykę krzywdy”, upatrujemy jednak długofalowych destrukcyjnych konsekwencji.

Słowa kluczowe: krzywda, resentyment, populizm, PiS, polityka historyczna, nowy autorytaryzm

\section{WPROWADZENIE}

Od początku kadencji PiS ma niesłabnące poparcie społeczne w okolicach 40\%. W tych sondażach pominąc można wyniki badań przeprowadzonych w marcu 2018 roku przez ośrodek Kantar Millward Brown SA, w których koalicja

* Dr hab., Centrum Europejskie; e-mail: m.rakusa-suszczewski@uw.edu.pl 
rządząca odnotowała 12-procentowy spadek poparcia w stosunku do wyników z 21 lutego, jak również nieznaczne wahania w tym zakresie odnotowane w innych badaniach. Sympatiom wyborców towarzyszy dość powszechne zadowolenie z życia na poziomie niemal analogicznym do wskaźników popularności partii rządzącej w Polsce. Według danych ośrodka badawczego CBOS pozytywne trendy dotyczą wielu obszarów życia: rośnie poczucie, że ogólna sytuacja w kraju zmierza w dobrym kierunku; sytuacja polityczna oraz gospodarcza poprawiają się, rodzinom żyje się lepiej, a ludzie są coraz bardziej zadowoleni z własnej sytuacji materialnej. Co ciekawe, wzrosła także liczba osób zaangażowanych społecznie [http://www.cbos.pl/PL/trendy/trendy.php?trend]. Jest to tendencja z pewnością rzadko spotykana w najnowszej historii Polski. Trzeba jednak zaznaczyć, że tych, którzy oceniają aktualną sytuację w kraju dużo bardziej krytycznie, lub wręcz źle, jest niewiele mniej. Nieco wyraźniej te proporcje optymistów i pesymistów widać w monitorze TNS OBOP [http://www.tnsglobal.pl/monitor/]. Opinia publiczna w Polsce jest zatem bardzo spolaryzowana, a władza, jakkolwiek popularna, jest przez dużą część społeczeństwa nielubiana. Kontrowersyjne reformy systemu sprawiedliwości i edukacji, konfrontacyjny styl w polityce międzynarodowej, wyzywające działania w obszarze ochrony środowiska i zdrowia, działania policji, służb specjalnych itp. spotykają się niemal każdego dnia z potężną krytyką nie tylko opozycji politycznej, rozlicznych organizacji pozarządowych i inicjatyw obywatelskich, ale też dużej części społeczeństwa polskiego i międzynarodowej opinii publicznej, w tym rządów państw i ważnych instytucji chroniących ład demokratyczny na świecie i w Unii Europejskiej. Wysokie poparcie dla partii rządzącej, które można bez wątpienia interpretować jako sukces polityczny, okupione jest zatem wewnętrznym konfliktem społecznym, przygnębiającymi animozjami w przestrzeni publicznej i życiu prywatnym. Głębokie i rozdzierające poczucie wzajemnej niechęci, wrogości, a nawet nienawiści, przypomina cichą „wojnę domową” - jak wyraził się Lech Wałęsa. Powszechne poczucie zadawanego gwałtu, niezrozumienia i niesprawiedliwości dotyczy jednak wszystkich, zarówno zwolenników, jak i przeciwników „dobrej zmiany”.

Środowisko krzywdy, wraz z silnymi antagonizmami społecznymi, zdaje się być zasadniczym czynnikiem utrzymującym poparcie i niechęć wobec partii władzy. Innymi słowy, wewnętrzne podziały, intensywnie przeżywana opozycja wroga i przyjaciela, jedności i obcości, rosnące poczucie konfliktu, a nawet trwającej walki między politycznymi obozami, konsolidują coraz bardziej odległe od siebie elektoraty z ich alternatywnymi wykładniami tożsamości i krzywdy. W świetle przywołanych na początku tendencji upatrywanie w tym jedynej, czy 
nawet zasadniczej, przyczyny poparcia stanowiłoby nadużycie. Z pewnością niemało obywateli, w tej lub innej formie, bezpośrednio skorzystało z podjętych decyzji i reform, jest także wielu takich, którzy uważają, że w dłuższej perspektywie przyniosą one powszechne i trwałe korzyści. Pomijamy tu takie kwestie, jak międzynarodowa koniunktura ekonomiczna, nieskrywana sympatia Kościoła katolickiego dla niektórych projektów legislacyjnych rządu, propagandowy charakter mediów publicznych czy polityka kadrowa PiS, polegająca na przetasowaniu kadr w administracji rządowej na absolutnie bezprecedensową skalę [Paczocha 2018].

Naszą uwagę przykuwają przede wszystkim zagadnienia tożsamości i uznania, które najlepiej opisywać w języku filozofii polityki, psychologii społecznej i filozofii kultury. W ten sposób będziemy też analizować problem krzywdy w politycznej logice PiS. W celu opisania tego - póki co - intuicyjnie pojmowanego mechanizmu należy równolegle wyjaśnić trzy podstawowe kwestie. Po pierwsze, w jaki sposób realna i wyimaginowana krzywda, tj. mówienie o krzywdzie i legitymizowanie własnej działalności przez odwoływanie się do niej, staje się narzędziem populizmu i przedmiotem „,polityki krzywdy”. Innymi słowy, będziemy wyjaśniać funkcjonalność krzywdy w logice trwałych manichejskich antagonizmów zaprzęgniętych w populizm. Po drugie, przedstawimy, w jaki sposób dyskurs krzywdy uobecniał się w najnowszej historii politycznej Polski po 1989 roku. Zwrócimy tu uwagę w szczególności na zasadnicze kontrowersje polityki historycznej związane z pojęciem krzywdy. Po trzecie, wyjaśnimy, jaki rodzaj przewrotnej satysfakcji może przynosić odwoływanie się do krzywdy. Oznacza to, że odwołamy się w tej interpretacji do pojęcia resentymentu, który perwersyjnie leży u źródeł popularności partii rządzącej. Na koniec podzielimy się naszymi uwagami na temat szkodliwych, a nawet destrukcyjnych konsekwencji, jakie może mieć dla obywateli „polityka krzywdy” i jej utrwalanie.

\section{KRZYWDA JAKO NARZĘDZIE POPULIZMU PIS}

Zaznaczmy krótko, że krzywda należy do wielowymiarowych i fundamentalnych pojęć polityki przynajmniej od czasów Platona, zajmuje pierwszorzędne miejsce w chrześcijańskiej etyce cierpienia czy w wyrastających z oświecenia projektach liberalnych. „Zasada krzywdy” Johna Stewarta Milla, wedle której wolność człowieka może być ograniczona jedynie w celu zapobieżenia cierpieniom innych, odzwierciedla ideały francuskiej Deklaracji Praw Człowieka i Obywatela. W tradycji politycznego realizmu, od Tukidydesa po Carla Schmitta, krzywda traktowana była jako nieusuwalna cecha życia społecznego i suwerennych wspól- 
not politycznych, które w obronie własnej władzy, interesów, bezpieczeństwa czy wewnętrznej jedności dysponują pełnym prawem do stosowania przemocy, a tym samym posiadają legitymizację do zadawania krzywdy. Świadomość związanych z tym problemów postępuje wraz z sekularyzacją i kolejnymi generacjami praw człowieka. Emancypacja pogłębia zakorzenione w zdrowym rozsądku dominujące wyobrażenia krzywdy, bólu, traumy, piętna, eksploatacji czy poniżenia. Krzywda ukonkretnia się jako doświadczenie różnych grup społecznych, zwierząt i środowiska naturalnego. Zasadniczy wkład w rozjaśnianie jej destrukcyjnego wpływu na kondycję tożsamości (uznanie i godność), w jej indywidualnym i zbiorowym wymiarze, miały w XX wieku nauki społeczne, w tym zwłaszcza socjologia krytyczna [Copson 2018]. Problematyka krzywdy ukrytej i nieprzepracowanej jest także szeroko dyskutowanym tematem na gruncie badań interdyscyplinarnych oraz psychologii [Tulibacki 2003; Mellibruda 1995]. Krzywda, która odwołuje się do szkody, niesprawiedliwości oraz ryzyka, a także wzywa do ich cywilizowanego bądź siłowego przezwyciężenia, jest punktem odniesienia dla reguł prawa (sprawiedliwości), polityki bezpieczeństwa, równości i dystrybucji (polityki społecznej) etc. Krzywda może wyrażać aktualne poczucie niesprawiedliwości, ale też dotyczyć tragicznych doświadczeń z przeszłości, często sztucznie wskrzeszanych w polityce historycznej. Wieloznaczność i symboliczny ciężar gatunkowy pojęcia krzywdy, tak mocno osadzonego w różnych tradycjach i światopoglądach, sprawia, że łatwo nim manipulować i wykorzystywać je do działań o charakterze populistycznym. Podkreślmy, że interesuje nas tu nie tyle samo pojęcie krzywdy, które było przedmiotem licznych badań i samo w sobie jest potężnym zagadnieniem psychologii społecznej i badań nad kulturą [por. Feinberg 1987; Linklater 2011], ile „polityka krzywdy”, rozumiana tu całościowo, zarówno jako wydobywanie i politycznie uzasadniona rekonstrukcja rzeczywistych krzywd, jak i tworzone na wyrost i z myślą o bieżącej polityce artefakty i fetysze.

Oddzielny i ważny problem, który - stosownie do zakresu tego artykułu - należy uwzględnić jako możliwy pierwiastek „polityki krzywdy”, wiąże się zatem również ze zjawiskiem resentymentu: nieuświadomioną inklinacją do eksponowania stłumionych krzywd i urazów, sfrustrowanych potrzeb i braku uznania, za czym idzie również chęć rewanżu, odbieranie wartości innym i potępianie wszystkiego, czego potajemnie się pożąda [por. Merton 1982: 219]. Mechanizm, w którym poczucie krzywdy, bezsilność, skrywane urazy i zawiść organizują życie moralne, uczuciowe i praktyki społeczne, a w dłuższej perspektywie prowadzą do rozkładu moralności i życia wspólnoty, opisał Fryderyk Nietzsche [Nietzsche 2003]. W jego genealogii zakłamanej moralności szczególne miejsce zajmuje etyka judeochrześcijańska, która - według niemieckiego 
filozofa - poczucie krzywdy i słabość przekuła w wartość. Max Scheler wiąże natomiast resentyment z rozwojem moralności mieszczańskiej i demokratycznej, a zatem wyjaśnia go charakterem struktury społecznej, która wzmacnia poczucie deprywacji: „Największy ładunek resentymentu - pisze socjolog-musi posiadać takie społeczeństwo, w którym, jak w naszym, ręka w rękę idą mniej lub więcej równe prawa polityczne i inne, względnie publicznie uznane formalne równouprawnienia społeczne, wraz z bardzo dużymi różnicami w faktycznej władzy, faktycznym posiadaniu i faktycznym wykształceniu" [Scheler 1977: 41]. Takie usytuowanie resentymentu jako ekspresji reaktywnych uczuć w środowisku samej demokracji, i wobec nasilających się różnic, ma zastosowanie również wobec Polski [Kapralski 1989; Weryński 2017]. Z pewnością uczucia takie mogą towarzyszyć odsuniętym i przegranym transformacji (,transformacyjny resentyment”) [Fatyga 2005], aspirującemu drobnomieszczaństwu czy pokrzywdzonym klasom ludowym. Popularność PiS oraz logika politycznych sympatii i antypatii może wynikać z przebudzonych resentymentów różnych grup społecznych, z bezsilności i tłumionej krzywdy, która, świadomie bądź nie, bywa dziś podsycana przez polityków w imię „dziejowej sprawiedliwości”, „moralnego prawa” itp. Bywa, że wypełnione krzywdą toksyczne uczucia przywódców i liderów politycznych niczym zaraźliwa choroba dotykają obywateli niepewnych własnej tożsamości. To, co bierzemy za charyzmę władzy, może być wówczas pracą ,niskich” emocji i wypartych uczuć, które nagle powracają z siłą niedającą szansy na ich kontrolę, jak w Rwandzie czy Południowej Afryce, gdzie bolesne i wypierane zaszłości niszczą sferę publiczną [Capriles 2012: 2-3]. Resentyment jako złożone uczucie buntu i bezsilności wobec „obcych” i ,silnych” stanowi coraz popularniejszą perspektywę w badaniach nad postkolonialną świadomością obywateli Europy Środkowo-Wschodniej, w tym Polski [Gundurowa 2007; Thompson 2007; Sowa 2011].

Dodać trzeba, że otwarte mówienie o krzywdach nie zawsze musi wyrażać, przyobleczone w fałszywe ideały, resentymenty. Trudno jednoznacznie wskazać, co jest resentymentem, a co ekspresją doznanej rzeczywiście krzywdy. Naszą czujność muszą wszakże budzić bezkrytycyzm i uogólnienia. Jak przekonuje Scheler, człowiek dotknięty resentymentem nierzadko bezkrytycznie afirmuje odległe, mityczne i fantastyczne „obszary historycznej przeszłości”. Z tej perspektywy można zrozumieć przywracanie przez PiS pamięci o ,żołnierzach wyklętych” $i$ ich bohaterstwo w walce o niepodległość. Jednak spuszczanie zasłony niewiedzy na ciemne strony ich walki, idealizacja niewinności i bohaterstwa zawierają w sobie element podejrzanej egzaltacji cechującej resentyment, którego działanie zamienia wady w zalety. Podobnie usuwanie symboli komunizmu, w tym również zmiana 
nazewnictwa ulic, ma jedynie częściowe uzasadnienie, gdyż nie każdy komunista był człowiekiem pozbawionym wartości. Wyrazem resentymentu będzie, słyszane w przestrzeni publicznej, małoduszne poniżanie „wykształciuchów” i profesorów akademickich, pogarda wobec „salonu” czy wzywanie do reedukacji sędziów. Można mieć wątpliwości, czy osadzone w resentymencie krytykowanie wszystkiego, co obowiązujące (,ruch przeciw kulturze” [Lipowicz 2010: 41]), trwale wzmacnia określone postawy polityczne. Uderza nas tu wszakże dwuznaczna rola populizmu. Wyjaśnimy to poniżej.

To, co zwykle określa się mianem populizmu, zazwyczaj zaciemnia złożone przyczyny i uwarunkowania społecznego niepokoju, który go rodzi. Pojęcie to bywa również nadużywane. Nie zmienia to jednak faktu, że istnieje odrębne zjawisko populizmu, które oddziałuje na praktykę polityczną również rządzącej dziś partii. Możemy wymienić tu dwa komplementarne sposoby rozumienia populizmu, urzeczywistniające się także w polityce PiS. Pierwszy, nazwijmy go ideologicznym, wiąże się z podsycanym w społeczeństwie przekonaniem, że istnieje fundamentalny i faktyczny podział społeczeństwa na dobrych i złych. W roli tych pierwszych występują skrzywdzeni, najczęściej prosty lud, wiedziony rzekomo szlachetną wola, obdarzony wyrazistymi i jednoznacznymi cechami lub ich zbiorem (np. pozycją społeczna, pochodzeniem narodowym, silną identyfikacją ze wspólnotą, określonym wyznaniem, a nawet rasa). Z drugiej strony figurują zdemoralizowane, skorumpowane i spiskujące elity, których obce pochodzenie odzwierciedla nieczyste i pokrętne intencje, w gruncie rzeczy chęć zadania krzywdy [Mudde 2004: 542-563]. W tej ideologicznej, niepozbawionej resentymentu i uogólnień wykładni mamy do czynienia z pewnym imaginarium trwałego konfliktu i krzywdy, które umożliwiają porządkowanie świata w sytuacjach kryzysowych, a takiej - jak twierdzą politycy PiS - sprostać trzeba właśnie dziś. Tak ideologicznie, czy wręcz ontologicznie, podbudowany populizm służy dziś dyskredytacji elit społecznych: nie tylko polityków i biznesmenów, ale i żołnierzy, sędziów, nauczycieli, dziennikarzy czy ludzi sztuki, słowem, całego establishmentu. Są oni nie tylko beneficjentami transformacji systemowej, „ciemnych” postkomunistycznych i europejskich układów, ale zawdzięczają swoją pozycję ofiarom innych i działaniom ze szkodą dla Polski. Jak pisze Henryk Domański: „Nie wiadomo dokładnie kto należy do establishmentu, ale nie o definicję tu chodzi. Zadaniem PiS jest bowiem obrona przed establishmentem zwykłego Polaka. Ponieważ podział na establishment i społeczeństwo, które wymaga ochrony, funkcjonuje w przekazie publicznym, stał się on faktem, który w jakimś stopniu stanowi podłoże konfliktów społecznych" [Domański 2017: 39]. Uporządkowanie spraw publicznych oznacza również „faktyczne” usunięcie 
establishmentu bądź jego szeroko zakrojoną resocjalizację, której dalekosiężne konsekwencje mają się urzeczywistnić w bliżej nieokreślonej idei „kontrrewolucji kulturalnej" zapowiadanej przez Jarosława Kaczyńskiego i Wiktora Orbana na Forum w Krynicy. Idea skorumpowanych, zdemoralizowanych i nieodpowiedzialnych elit wpisuje się tu w szerszy pejzaż "nowych złych czasów” - powszechnego zakłamania w dobie liberalizmu „róbta co chceta”, „poprawności politycznej” i kultury tzw. ,postprawdy”. Nie ulega wątpliwości, że ta niezwykle ogólnikowa diagnoza cywilizacyjna PiS uzyskuje również silne wsparcie ze strony niektórych środowisk katolickich w Polsce, ogarniętych apokaliptyczną wizją ,cywilizacji śmierci”. Przede wszystkim jednak koresponduje bezpośrednio z odczuciami i przekonaniami klasy ludowej, w której partia odnajduje ważną część swojego elektoratu [Gdula 2014: 20].

W drugim rozumieniu, które określamy mianem prakseologicznego, populizm to specyficzna forma komunikacji, pewien rodzaj dyskursu i styl w praktyce politycznej. Populizm pojmujemy tu jako technikę i strategię sprawowania władzy, która opiera się na biało-czarnych interpretacjach świata, nie zaś na ontologii życia społecznego [Panizza 2005; Kazin 1995]. Silne podziały tworzone w ramach tych interpretacji stanowią tu narządzie osiagania celów politycznych i element zarządzania psychologią wyborczą. Pierwotnie dyskursywny charakter zjawisk uzyskuje tu status zjawisk całkowicie realnych i rzekomo zakorzenionych w autentycznych podziałach. Pojęcie krzywdy uruchamia gęsty zestaw antagonizujących pojęć: winy i kary, cierpienia i odkupienia, niesprawiedliwości i zadośćuczynienia, poniżenia i uznania, zdrady i zemsty, wroga i sojusznika, wiktymizacji i gloryfikacji itd. Robert Piłat twierdzi, że „krzywda ustanawia relację" [Piłat 2003]. Dodajmy, że jest to nie tylko relacja między skrzywdzonym i krzywdzicielem, ale rozległa relacja społeczna między obywatelami schwytanymi w rozliczne opozycje. Krzywda ustanawia zatem nie tylko relacje, ale i różnice, które w manichejskim świecie populistów mogą jedynie podsycać konflikty. Mówimy tu zatem o - mniej lub bardziej świadomym - stosowaniu języka podziałów („,komuniści i złodzieje”; ,wrogowie chrześcijaństwa”, ,gorszy sort”, „resortowe dzieci”, „zdrajcy i targowiczanie” „zboczeńcy i degeneraci” itp.). We wszystkich tych przypadkach stygmatyzowania potegowana jest zarazem krzywda okaleczonych przez domniemane układy patologiczne oraz postępującą zapaść moralną. Liczne badania potwierdzają również skuteczność tego typu retoryki krzywdy w warunkach silnych podziałów klasowych z rozbudzonymi aspiracjami do awansu bądź z silnym poczuciem wykluczenia i deprywacji. Do tych podziałów na osi „góra-dół” dochodzą oczywiście relacje międzynarodowe, w których piętnowane są inne państwa, narody i religie (w tym emigranci), 
innymi słowy, antagonizmy i resentymenty tworzone na osi „swoi-obcy” [Gdula, Sutowski 2017: 10]. Jak podkreślają psychologowie, takie dzielenie ma destrukcyjny wpływ na życie psychiczne obywateli, prowadzi do dehumanizacji, wzrostu agresji i wykluczenia [List otwarty do Pana Prezydenta Rzeczpospolitej Polskiej Andrzeja Dudy, Pani Premier Beaty Szydło oraz Pana Marszałka Sejmu Marka Kuchcińskiego...].

Populizm - w obu przypadkach - wyraża moralną i praktyczną potrzebę uproszczonych definicji świata i jednoznacznych rozwiązań. Dotyczy to zarówno populizmu lewicowego, który charakteryzuje Amerykę Południową, jak i populizmu prawicowego typowego dla Europy, w tym również dla partii rządzącej w Polsce. Swoją potrzebę ,jasności” takie populistyczne siły najczęściej przypłacają wulgaryzacją obrazu rzeczywistości i zasad sprawiedliwości. Ich antynaukowy charakter i uzależnienie od charyzmatycznego przywództwa są tego ilustracją. Populistyczna eschatologia, w której pojęcie krzywdy odgrywa kluczową rolę, rozbudza namiętności polityczne i czasami przyczynia się do ożywienia życia politycznego, w szczególności poprzez inkluzję wykluczonych bądź zmarginalizowanych dotąd obywateli, a przeciw establishmentowi. Sprawia to - jak podkreślają Noam Gidron i Bart Bonikowski - że badacze populizmu nie są zgodni, na ile jest on przejawem kryzysu, a na ile korektą demokracji i formą przywracania równowagi w dystrybucji władzy [Gidron, Bonikowski 2013: 18; por. Kaltwasser 2012]. Populiści nie bronią uniwersalnych praw, instytucji czy równowagi, ale zasady suwerennej większości demokratycznej i partykularyzmu politycznego, które są istotą demokracji większościowej. Dlatego właśnie, na użytek rewitalizacji polityki, niektóre prawicowe partie głównego nurtu i ich liderzy akceptują i adoptują ten populistyczny styl. Jarosław Kaczyński nie jest tu odosobniony. Prezydenci Nicolas Sarkozy i Silvio Berlusconi także stanowią bardzo znamienne przykłady [Musso 2013: 59]. Przy całej swojej uproszczonej wizji świata populizm może przynieść korektę demokracji jako jej brzydki, ale zarazem najbardziej autentyczny obraz [Arditi 2004: 139]. Wynika z tego jeszcze jedna rzecz, która świadczy - o sugerowanej wcześniej - dziwacznej dwuznaczności populizmu w jego związku z resentymentem. Jeżeli mianowicie populizm prowadzi do emancypacji niektórych grup społecznych, pogardliwie określanych mianem „ciemnogrodu”, a nawet rozładowania gniewu, to mógłby zarazem wydobywać je z poczucia niemocy i bezsilności (imposybilizmu), a tym samym stwarzać, w dłuższej perspektywie, szansę na normalność i likwidację środowiska resentymentów. Teza ta wydaje się jednak mało prawdopodobna wobec negatywnych konsekwencji ,polityki krzywdy”. 


\section{DYSKURS KRZYWDY W POLITYCE HISTORYCZNEJ}

Zwróćmy teraz uwagę na zasadnicze przesunięcie akcentów w najnowszej polityce historycznej, która $\mathrm{w}$ dużym stopniu, choć często nie expressis verbis, odwołuje się właśnie do pojęcia krzywdy. Tomasz Merta przekonywał, że zmiany te nie mogą wynikać z prawa do arbitralnej manipulacji, ale powinny odzwierciedlać stan społecznej świadomości i być przedmiotem konsensusu wspierającego tożsamość narodową [Merta 2005: 2]. W rozumieniu nieżyjącego już polityka, niegdyś silnie związanego z obecną partią władzy, oznacza to selekcję pozytywnych i bohaterskich doświadczeń z przeszłości. Wśród godnych naśladowania przykładów z lat 80 . Merta wspominał konkretnie jedynie o heroicznym wysiłku zachowywania pamięci o Katyniu czy demaskowaniu fałszu i perfidii władz podyktowanym - skądinąd słuszną - walką o przetrwanie narodu. Polityka historyczna w III RP rozerwała ścisły związek między ,pamięcią i nadzieją", co dla historyka miało charakter antypolityczny i antydemokratyczny [Merta 2005: 5]. Historię zaczęto traktować jako ,zbędny balast”, a nawet coś potencjalnie niebezpiecznego, przypominającego haniebne praktyki totalitarnej polityki historycznej. Prymat demokracji proceduralnej odwodził też od potrzeby ustanowienia ,podstawowego konsensusu” w tym zakresie. W gruncie rzeczy historię i odradzającą się myśl narodową zaczęto traktować jako potencjalne źródło krzywdy, zaś nowe „krytyczne” podejście - twierdzi Merta - miało służyć jedynie demaskacji i kompromitacji narodowych mitów. Tymczasem prawdziwy problem leży nie w megalomani narodowej, lecz w fatalnie niskiej samoocenie Polaków - jak sądzi Merta - a zmiana tego wymaga uczciwych dyskusji na temat mordu w Jedwabnem, rzezi wołyńskiej czy odpowiedzialności za krzywdę powojennych przesiedleńców różnych narodowości. Polityka historyczna powinna koncentrować się zatem na prawdzie, ale podstawowym punktem odniesienia są dla niej historyczne krzywdy i heroizm tych, którzy stawiali im opór.

Z praktyki politycznej PiS wiemy, że pamięć o bohaterskiej historii nieodłącznie wiąże się z podkreślaniem własnej krzywdy, nie zaś własnej winy. Myślę, że Tomasz Merta w eseju niekompletnie zdiagnozował ideę „krytycznej” polityki historycznej, która stanowiła część filozofii ,grubej linii” sformułowanej przez Tadeusza Mazowieckiego, jedynie jako wyraz przekonania o ,szkodliwej naiwności historii narodowej”. W swoim exposé pierwszy premier wolnej Polski deklarował: „rząd, który utworzę, nie ponosi odpowiedzialności za hipotekę, którą dziedziczy. Ma ona jednak wpływ na okoliczności, w których przychodzi nam działać. Przeszłość odkreślamy grubą linią. Odpowiadać będziemy jedynie za to, co uczyniliśmy, by wydobyć Polskę z obecnego stanu załamania" [Frag- 
ment exposé wygłoszonego przez Tadeusza Mazowieckiego 24 sierpnia 1989 r.]. W projekcie tym widzimy raczej próbę wzmocnienia samooceny Polaków, nie tyle przez przejmowanie winy, ile przez oddalenie wszelkich krzywd, które w strumieniu różnych argumentów przywoływał Merta. Projekt Mazowieckiego miał charakter wielkiej amnestii, która spuszczała zasłonę niewiedzy na wszelkie patologie i niesprawiedliwość, w których, chcąc nie chcąc, mieli udział niemal wszyscy obywatele PRL. Była to realistyczna, a nawet chrześcijańska deklaracja zapoczątkowania nowej historii, w której nie ma miejsca na wzajemne oskarżenia z tytułu doznanych krzywd i cierpień. Był to akt przebaczenia, ale zarazem „akt założycielski” czy „akt narodzin” - jak by powiedziała Hannah Arendt - a zarazem apel o solidarne budowanie przyszłości bez resentymentów i zawiści, w myśl słów Arystotelesa, iż: „Nie wolno nikomu przeciw nikomu występować w związku z wydarzeniami przeszłymi [...]" [Arystoteles 2001: 39]. Nie chodziło tu o zapominanie krzywd, ale pragmatyczną rehabilitację potrzebną do budowania zaufania społecznego na bazie nowych działań. Z punktu widzenia obecnej sytuacji możemy powiedzieć, że ten ambitny projekt, ujęty w prosty slogan, spalił na panewce, a krzywdy nie przedawnily się.

Nieco bardziej zniuansowane jest stanowisko Andrzeja Ledera, które pozwala nam włączyć problem krzywdy bezpośrednio w refleksję nad populizmem. Leder pisze, że: „Problemem III Rzeczpospolitej - podobnie jak jej poprzedniczki - była i jest niezdolność klasy politycznej do znalezienia w obrębie społecznego imaginarium politycznego słów i symboli znaczących, które włączyłyby poczucie krzywdy we wspólnotę republiki” [Leder 2014: 36], i dalej: „,[...] poczucie krzywdy w Polsce nie stworzyło języka politycznego" [Leder 2014: 37]. Przez język polityczny Leder rozumie język, który tworzy płaszczyzny współistnienia. W naszym rozumieniu taki pragmatyczny projekt przyświecał implicite Tadeuszowi Mazowieckiemu. W praktyce jego liberalnego środowiska przeradzał się on nierzadko w pogardliwe piętnowanie skrzywdzonych i pełnych gniewu, którzy żywią nienawiść i chęć odwetu, czerpiąc przy tym poczucie wyższości moralnej. Jednak , , [...] zaklinaniem ani pouczaniem - pisze Leder - a tym bardziej drwiną nie redukuje się nienawiści. Raczej ją się wzmacnia" [Leder 2014: 38]. Z drugiej jednak strony, istnieją radykalni „,rzecznicy odwetu i wściekłości”, którzy podniecają resentymenty i wskazują winnych swojej krzywdy. Ci zarzucają też zwolennikom liberalnej poprawności lekceważenie. Dodamy, że w tym „błędnym kole” - jak wyraża się Leder - krzywda i problem radzenia sobie z nią pozostaje centralnym problemem nie tyle debaty publicznej czy polityki historycznej, ile kondycji duchowej i emocjonalnej wszystkich obywateli. Niezależnie od odpowiedzialności obu stron trudnej dyskusji na temat krzywdy dziejowej, 
społecznej niesprawiedliwości, wykluczenia itd., frapujące uwagi Andrzeja Ledera zostawiają nas z poczuciem nieusuwalnego antagonizmu, który dziś jest instrumentalizowany w populistycznej polityce PiS w o wiele większym stopniu niż zaprzęgnięty w projekt politycznego współistnienia.

Prawo do mówienia o własnej krzywdzie i glorii urzeczywistnia się w prezentowaniu „polskiego punktu widzenia”. Jest to element polityki tożsamościowej i wizerunkowej PiS. W praktyce jednak ta rewizjonistyczna ,polityka pamięci” oznacza wzmocnienie instrumentalnego i propagandowego charakteru badań naukowych, programów edukacyjno-wychowawczych, upolitycznienie wyspecjalizowanych instytucji oraz tworzenie na zamówienie konkretnych produktów medialnych. W tym wydaniu polityka historyczna nie uwzględnia zróżnicowań pamięci zbiorowej, przestaje być efektem dialogu społecznego, a także popada w mitologię i dogmatyzm. Polityka historyczna utrudnia uchwycenie złożonych narracji historycznych, w rezultacie prowadzi do manipulacji, zawłaszczeń, a w ostateczności do społecznych podziałów i konfliktów. Jak odnotowują Biuro Rzecznika Praw Obywatelskich i organizacje pozarządowe (np. Nigdy Więcej), „polityka tożsamościowa” może współodpowiadać za wzrost nastrojów nacjonalistycznych i uprzedzeń. W tej postaci rodzi również pokusę ,rewanżyzmu", w imię wyrównywania krzywd. Innymi słowy, mówienie o krzywdzie ma również efekt odwrotny, to znaczy generuje krzywdę. Trudno bagatelizować ogrom zła wyrządzonego w myśl różnych historycznych stereotypów, uprzedzeń i fałszywych oskarżeń lekkomyślnie podsycanych przez polityków. Arbitralne roszczenia natychmiastowego uznania własnych krzywd przeradzają się w gwałt zadawany ludziom, którzy myślą i wyglądają inaczej. To między innymi sprawia, że polityka historyczna wzbudza w Polakach bardzo negatywne emocje [Kącka 2015: 68]. Gdy polityka historyczna służy bieżącym celom, „mamy wtedy do czynienia nie tyle z polityką historyczną, ile z polityką resentymentu, polegającą na chęci rozegrania bitew już kiedyś w przeszłości przegranych, wzięcia odwetu za minione krzywdy [rozstrzelenie: MRS], pokazania siły i pewności tym, od których kiedyś doznało się upokorzeń. Oznacza to kierowanie się w polityce nie bieżącą kalkulacją interesów [...] lecz tylko i jedynie chęcią wyrównania minionych krzywd, nawet ze szkodą dla realizacji obecnych celów" [Gałkowski, Gałkowska 2008: 55]. W ten sposób obywatele stają się zakładnikami motywacji i intencji polityków. Z taką sytuacją mamy do czynienia obecnie. PiS świadomie działa na polskich resentymentach i krzywdzie, a w gruncie rzeczy na społecznej bezsilności i potrzebie „wysublimowanej zemsty”, o której pisał Fryderyk Nietzsche, poszukując genealogii moralności [Nietzsche 2003: 22]. Jednak to, co jest 
szkodliwe dla życia publicznego, sieje i umacnia niezgodę, pozostaje wszakże ważnym czynnikiem poparcia politycznego dla tej partii, i wiary, że przyjdzie czas, gdy ,pierwsi będą ostatnimi”.

\section{REALIZM KRZYWDY I JEJ PERWERSJE}

Problem krzywdy społecznej, czy „podmiotowość krzywdy” [fr. sujet de tort] - jak pisze Jacques Rancičre - hańba „tych co się nie liczą”, jest oczywiście bardzo realny, a jego rozwiązywanie powinno być problemem polityki, a nawet istotą polityczności [Rancičre 1995: 162]. Być może właśnie leczenie krzywd, rozumiane jako walka z niesprawiedliwością ekonomiczną, stanowi przyczynę popularności PiS i nieco mglistego, ale pociaggającego wrażenia odradzania się polityczności, nad której zanikiem ubolewa duża część zarówno konserwatywnych, jak i postępowych filozofów, piętnujących brak decyzyjności, powszechny marazm i brak wyrazistych podziałów politycznych w świecie zdominowanym przez liberalny konsensus. Z całą pewnością PiS wprowadziło szereg reform brzemiennych w skutkach, pośród których Program 500+ zasługuje na największą uwagę. Oczywiście można sformułować szereg wątpliwości ekonomicznych i moralnych pod jego adresem, zastanawiać się nad alternatywnymi sposobami dystrybucji znacznych kwot przeznaczanych rokrocznie na ten program lub też roztrząsać dyskusyjne zasady sprawiedliwości, które leżą u jego podstaw, niemniej duża część obywateli realnie skorzystała z tego finansowego wsparcia, ale również politycznego uznania. Program ten uderzył zatem w realnie istniejące krzywdy. Ogólnie rzecz biorąc, „PiS - jak pisze znany ze swoich lewicowych zapatrywań Maciej Gdula - celnie wskazał najważniejsze problemy, jakie mamy z neoliberałami i współczesnym kapitalizmem, faktycznie reprezentuje p o kr z y w d z o n y c h [rozstrzelenie: MRS] i wprowadza rozwiązania, których lewica by się nie powstydziła" [Gdula 2018: 20].

Problem jednak leży jeszcze gdzie indziej. Argument i język krzywdy stały się bowiem nie tylko sposobem na artykułowanie niesprawiedliwości społecznej, własnego zniechęcenia i rozczarowania. Niespełnionym i pozostającym pod presją codziennych wyzwań często towarzyszy rzeczywista krzywda: zagubienie i poczucie wykluczenia, frustracja, a nawet zwyczajne zmęczenie; wielu ludzi ciagle jest krzywdzonych przez Państwo. Język deprywacji służy do wyrażania swoich zawiedzionych oczekiwań i aspiracji, a tym samym jest sposobem wyrażania potrzeby uznania. Krzywda jest szkodą sprzeczną z oczekiwaniami, doświadczoną nie z własnej winy, ale pod wpływem zewnętrznych okoliczności, najczęściej władzy. To ona odpowiada za wszelką sromotę. Takie przekonania 
potwierdzają badania dotyczące towarzyszącemu poczuciu krzywdy przeświadczeniu Polaków, że „inni ludzie nie wyświadczyli im więcej zła niż dobra” [Żemojtel-Piotrowska 2009: 39]. Skłonność do podkreślania własnych krzywd wielokrotnie zresztą diagnozowano w prowadzonych już wcześniej badaniach [Wojciszke, Baryła 2005; Szymków, Wojciszke, Baryła 2003; Kowalski 1996]. Taką umysłowość, wedle Aleksandra Zinowiewa, reprezentuje również homo sovieticus, któremu specyficznie polski charakter nadał Józef Tischner. Dziedzictwo komunizmu przyjmuje tu formę duchowego i moralnego okaleczenia, które wyraża się w poczuciu krzywdy ze strony władzy, ale też w oportunizmie, agresji, braku odpowiedzialności, poddańczości i roszczeniowości [Zinowiew 1987; Tischner 1992].

Prawo do mówienia i podkreślania swoich krzywd, ale też zwyczajny polski defetyzm uzyskały mocne wsparcie w polityce PiS, które buduje swój populistyczny kapitał na ciagłych antagonizmach. Zagospodarowana została rodzima skłonność do malkontenctwa i pesymizmu, które, wedle sondażu przeprowadzonego przez ośrodek badawczy CBOS w lipcu 2015 roku, stanowią dość charakterystyczną przypadłość narodową [por. Wociszke, Baryła 2002]. Co ciekawe, nie wyklucza to również ogólnego zadowolenia z życia deklarowanego przez Polaków, co odnotowano m.in. w Diagnozie Społecznej z 2015. Paweł Śpiewak podkreśla, że „Kaczyński eksploatuje różnego rodzaju krzywdy” - wyimaginowane i realne - które budują poparcie dla jego polityki [https://oko.press/socjologia-kaczynskiego-prof-spiewak-nikt-mi-mowi-zajmij-sie-lepiej-schetyna/]. Doprecyzujmy to, wskazując różne kategorie krzywdy przywoływane w przestrzeni publicznej przez liderów PiS: „,krzywda narodowa”, „krzywda katastrofy smoleńskiej”, „krzywda komunizmu”, ,krzywda aborcji eugenicznej”, „krzywda dzieci oddanych homoseksualistom”, „zadośćuczynienie i rachunek za krzywdy wyrządzone w czasie wojny”, „krzywda reprywatyzacji” etc. Nie chodzi tu o to, że z tymi poszczególnymi zjawiskami nie wiążą się rozmaite krzywdy, ile o fakt niezwykle uogólnionej definicji krzywdy, a więc nadużycie pojęcia, które sprawia, że zaczynamy funkcjonować w świecie ofiar i zbrodniarzy, niewinnych i oprawców, w świecie zła, któremu władza może dać odpór. Mamy nadzieję, że czytelnik wybaczy nam literacki wtręt, ale tę „kulturę krzywdy” dobrze wyrażają słowa Marka Hłaski, który pisał, że Polska to kraj: „,...] w którym każdy łajdak, zanim zdążył innym podstawić nogę i sam wpaść pyskiem w błoto - uważa się za człowieka skrzywdzonego przez historię" [Hłasko 1991].

Formułowane w poczuciu krzywdy roszczenia daleko wykraczają poza przysłowiowe „minimum socjalne”. Częściowo zwraca na to uwagę Maciej 
Gdula, kiedy pisze: „Z jednej strony PiS cieszy się poparciem osób wchodzących w rolę o fi a r y [rozstrzelenie: MRS] szukającej przez politykę sprawiedliwości, z drugiej poparcie dla PiS-u wiąże się z realizowaniem aspiracji klasy średniej do kontroli i panowania" [Gdula 2018: 72]. Jednocześnie socjolog podkreśla, że poparcie to nie jest jedynie „odreagowywaniem roli ofiary”, ale wiąże się z innymi aspiracjami, np. do władzy i kontroli (mocy), w czym upatruje istoty, charakterystycznego dla władzy PiS ,nowego autorytaryzmu” [Gdula 2018: 76, 79]. Z naszego punktu widzenia są to dwie strony tego samego medalu. Mówienie o krzywdzie bowiem zwykle odwołuje się do zaprzepaszczonych szans, niespełnionych marzeń i zawiedzionych oczekiwań, a w gruncie rzeczy do własnej bezsilności i - właśnie - braku mocy. Hasło wyborcze PiS w 2015 roku brzmiało: „damy radę”. Jego pozytywny i ambitny wydźwięk wyraża jednak głęboką frustrację: „wcześniej nie dawaliśmy rady”. Krzywda i poszukiwanie mocy idą zatem razem. Nie można również wykluczyć, że poza propagandą był to przejaw myślenia życzeniowego [wishfull thinking], które Antoni Kępiński w swoim języku psychiatrii humanistycznej przypisywał typom histerycznym. Przypadłość ta, którą autor Psychopatii dostrzegał w polskim charakterze narodowym, dotyczy ludzi niezdolnych do rozgraniczenia sfery marzeń i rzeczywistości, sfery idealnej i realnej, a także doznających w związku z tym ciągłego poczucia krzywdy i niespełnienia [Kępiński 2013: 102].

Podszyty idealizmem, symboliczny wyraz aspiracji do mocy wyraża slogan „powstawania Polski z kolan”, przywoływany przez polityków PiS, zwłaszcza w odniesieniu do polityki zagranicznej. Jego wymowy oraz siły nie sposób wszakże wyjaśnić racjonalnie i jedynie w odniesieniu do kwestii suwerenności narodowej. Z pewnością kryje on głębokie poczucie upokorzenia, kompleks niższości i wielorakie resentymenty, nie mówiąc o podtekstach religijnych. Odnajdujemy tu również potrzebę „wyrwania się” z własnej mizerii, marzenie o nowym statusie i lepszej pozycji społecznej, możliwość wyrównania własnych rachunków, a może nawet odnalezienie swojej „mesjańskiej roli w procesie historycznym" [Gdula 2018: 62]. Aspiracje te zasadzają sięjednak na krzywdzie, która wyznacza tu szczególnie atrakcyjny dla Polaków kanon opisu własnej sytuacji życiowej. W zantagonizowanym i moralizującym środowisku krzywdy duża część obywateli odnajduje swoje naturalne środowisko życia. Chociaż społeczeństwo utwierdza się w poczuciu goryczy i braku zaufania, to zarazem czerpie $\mathrm{z}$ tego liczne korzyści. Stąd jego perwersja, a w ostateczności degenerujący charakter.

Podkreślmy raz jeszcze, że tendencja, o której tu piszemy, ma częściowo charakter reakcyjny i stanowi odpowiedź na ekspansję liberalnego projektu cywilizacyjnego, ofensywę krytycznego i czasami trudnego do zaakceptowa- 
nia racjonalizmu oraz „hegemonię” ideałów społeczeństwa konsumpcyjnego ukierunkowanego na awans, samorealizację i sukces. W powszechnej praktyce wyrażania swoich potrzeb w języku doznawanej krzywdy i odarcia, w klimacie oskarżeń i antagonizmów, dostrzegamy specyficzną, i zapewne charakterystyczną dla dużej części Europy Wschodniej, skłonność [Petersen 2002; Sharafutdinova 2016; Creet 2013; Hladik 2009]. Z pewnością ma ona swoje liczne uzasadnienia w dramatycznej historii, krwawych wojnach, doświadczeniu totalitaryzmu, czy - jak pisze Jan Sowa - w krzywdzie „skolonizowanych”. Być może nadal odgrywają swoją funkcję, ukryte w języku i społecznej podświadomości, mity mesjanistyczne uzasadniające metafizyczną i historyczną celowość narodowej, ale i własnej krzywdy. Poczucie niepewności, zagrożenia i obsesja uznania mogą podsycać krzywdę we wszystkich państwach pogranicza niepewnych swego losu. $Z$ tego też względu do polityki PiS bardziej wydaje się pasować pojęcie ,polityki krzywdy” niż „polityki nowego autorytaryzmu”. Jak podkreśla Krystyna Skarżyńska, wielu upatruje w doświadczeniu krzywdy ,jądra polskości” [Skarżyńska, Przybyła, Wójcik 2012: 335]. Na koniec wypada nam zatem wyjaśnić, dlaczego odwoływanie się do krzywdy jest dla ludzi, a w szczególności dla Polaków, kuszące i jakie mogą być tego długofalowe konsekwencje.

Odwoływanie się do doświadczanych krzywd pozwala na uzyskanie samousprawiedliwienia, krzywda może więc działać jak wymówka i chronić przed oceną. Jest to szczególnie przydatne w warunkach silnej konkurencji i rywalizacji, która niewątpliwie doskwiera coraz większej rzeszy ludzi. Mówienie o krzywdzie uodparnia również na krytykę i minimalizuje rozczarowania. Nie inaczej jest w przypadku eksponowania krzywd narodowych. Akceptacja przekonań o wyjątkowych krzywdach kolektywnych idzie w parze z przekonaniem o własnej moralności i wierności własnym wartościom [Skarżyńska, Przybyła, Wójcik 2012: 337]. Podkreślanie własnych krzywd wzmacnia „kolektywny narcyzm”, a tym samym wyidealizowany obraz swojej wspólnoty, a także skłonność do gloryfikacji i przypisywania jej nadzwyczajnych cech. Jan Stanisław Bystroń określał to mianem „megalomanii narodowej”. „Przypuszczamy - pisze Skarżyńska i inni - że są osoby, dla których kolektywne cierpienia własnego narodu wzmacniająjego wartość, a identyfikacja z nim i ich niepewną samooceną wiąże się z oczekiwaniami dobrego traktowania oraz spełniania pewnych roszczeń jako odpłaty za dawne grupowe krzywdy" [Skarżyńska, Przybyła, Wójcik 2012: 337]. Krzywda zatem usprawiedliwia roszczenia. Im większe poczucie krzywdy, tym większa skłonność do nieuprawnionych, a nawet niemoralnych żądań [Lewicka 2002]. Podkreślanie krzywd, a szerzej, marudzenie i psioczenie na wszystko, jest nie tylko formą komunikacji, ale sposobem na budowanie więzi z innymi: 
„dla osób o niskim kapitale społecznym narodowe cierpienia i doznawane krzywdy mogą być łatwiejsze do zaakceptowania (niż inne pozytywne charakterystyki grupy, jak na przykład sukces ekonomiczny) jako podstawa identyfikacji z grupą ponieważ nie zagrażają ich samoocenie" [Skarżyńska, Przybyła, Wójcik 2012: 338]. Podkreślanie własnych krzywd staje się w ten sposób antidotum na deficyt realnych i bliskich więzi wsparcia społecznego. W końcu, przywiązanie do własnej krzywdy pozwala odrzucać własną odpowiedzialność za krzywdy, które się samemu wyrządziło. Tendencja ta narzuca się w szczególności w badaniach na temat związków polsko-żydowskich, w kontekście swoistej rywalizacji w cierpieniu: symbolicznego sporu o to, kogo bardziej doświadczyła wojna [Krzemiński 2001].

Istnieje zatem wiele powodów, by dostrzec funkcjonalność popularnego w Polsce romantycznego aforyzmu, jakoby „cierpienie uszlachetniało”. Wspieranie się krzywdą nie tylko jednak daje złudzenie mocy i pozwala ukryć własne słabości i niedostatki. W dłuższej perspektywie ma - jak przekonują psychologowie - również głęboko demoralizujący i destrukcyjny wpływ na życie społeczne i polityczne. Konsekwencje tego można dostrzec już dzisiaj. Podkreślanie własnych krzywd bynajmniej nie mobilizuje ludzi do aktywności i zabiegania o lepszy świat. Wręcz odwrotnie, jest ono negatywnie skorelowane z dbałością o instytucje publiczne, pielęgnowaniem dobrych relacji oraz szukaniem wsparcia i zaufania społecznego [Skarżyńska, Przybyła, Wójcik 2012: 337]. Przeszacowywanie własnych cierpień i krzywd, skupianie uwagi jedynie na własnej martyrologii ściśle wiąże się z poważnymi brakami w zakresie wiedzy historycznej i znajomości realnych problemów własnego kraju. Co gorsze, prowadzi do bezkrytycyzmu i zakłamania. Powszechna niechęć Polaków do uznania historycznie udokumentowanych aktów antysemityzmu, a nawet zbrodni przeciw narodowi żydowskiemu w czasie II wojny światowej, która ujawniła się w sposób nieoczekiwany z ogromną siłą w czasie nowelizacji ustawy o IPN, innymi słowy, niechęć do przyjęcia własnej winy, w miejsce własnej krzywdy, ma znamiona wypieranej kolektywnej rozpaczy wobec zbrukania nieposzlakowanego autoportretu narodu [Cichocka, Golec de Zavala 2011]. Środowisko krzywdy ma jeszcze inne konsekwencje: umacnia mianowicie poczucie zagrożenia, a także podejrzliwość i skłonność do oceniania innych jako potencjalnych antagonistów i wrogów. W nadużywanym przez PiS sformułowaniu „totalna opozycja” - jak podejrzewamy, świadomie ukutym dla nazwania krytyków rządu - odnajdujemy w rzeczywistości nie tylko inwektywę, ale wyraz skrywanej niechęci i własnej opozycji wobec wszelkiej krytyki, która postrzegana jest jako wroga, obca i krzywdząca, tj. nastająca zarówno na interes Polski, jak i samej władzy. Poczucie krzywdy wzmacnia wspólnotowy egoizm, 
który prowadzi do lekceważenia bądź instrumentalnego traktowania innych, oraz braku empatii wobec ich cierpienia. Gloryfikacja własnej wspólnoty narodowej w parze z silnym poczuciem krzywdy narodowej wzmacnia również wrogość i agresję, co wydaje się jego szczególnie ciemną stroną.

\section{PODSUMOWANIE}

Spośród wszystkich doznanych krzywd najlepiej pamiętamy te doznane niedawno. Widać je w polityce historycznej, która nie wykracza zazwyczaj poza XX wiek i czasy najnowsze - te po 1989 roku, które w języku PiS wypełnia niesprawiedliwość i krzywda. Ta narracja nie tylko porusza wielu obywateli, ale zwyczajnie im odpowiada. Schlebia resentymentom, niskim instynktom zemsty i rewanżu, ukrywa też liczne kompleksy, a czasami zwykłe niepowodzenia i zmęczenie. Mówienie o krzywdach, które się samemu wyrządziło, jest głęboko deprymujące i przysparza nieprzyjaciół, burzy mity i jest „kalaniem własnego gniazda”. Z pewnością jest również wielu takich, którzy własną odpowiedzialność chcą przenieść na innych, mamiąc własną cnotą i dobrymi intencjami. Stąd popularność polityków nawołujących do vendetty i rozliczenia wysokiego ,rachunku krzywd" - pisze krakowski historyk Łukasz Tomasz Sroka [Sroka 2008: 137]. $\mathrm{Z}$ naszego punktu widzenia, tu wyartykułowanego w odniesieniu do interdyscyplinarnych dyskusji na temat polityki historycznej i krzywdy, obecna władza cieszy się poparciem, czerpiąc z zasobów społecznego poczucia niesprawiedliwości, które nieustannie i na wiele różnych sposobów podsyca.

\section{BIBLIOGRAFIA}

Arditi Benjamin. 2004. "Populism as a spectre of democracy: a response to Canovan". Political Studies 52: 135-143.

Arystoteles. 2001. Ustrój polityczny Aten. W: Dzieła Wszystkie, fragment 39. Warszawa: Wydawnictwo Naukowe PWN.

Capriles Ruth. 2012. Leadership by resentment: from 'ressentiment' to redemption. Cheltenham, Northhampton: Edward Elgar Publishing.

Cichocka Aleksandra, Agnieszka Golec de Zavala. 2011. Kolektywny narcyzm a sprawa polska. W: Wobec obcych. Zagrożenia psychologiczne a stosunki międzygrupowe, M. Kofta, M. Bilewicz (red.), 232-247. Warszawa: Wydawnictwo Naukowe PWN.

Copson Lynne. 2018. A Sociology of harm. Bristol: Policy Press.

Creet Julia. 2013. "The house of terror and holocaust memorial center: resentment and melancholia in post-89 Hungary". European Studies 30: 29-62. 
Domański Henryk. 2017. Stratyfikacja klasowa w Polsce 1982-2015. W: Klasy w Polsce, teorie, dyskusje, badania, konteksty, M. Gdula, M. Sutowski (red.), 16-39. Warszawa: Instytut Studiów Zaawansowanych.

Fatyga Barbara. 2005. Dzicy z naszej ulicy. Antropologia kultury młodzieżowej. Warszawa: Uniwersytet Warszawski.

Feinberg Joel. 1987. Harm to others. Oxford: Oxford University Press.

Gałkowski, Stanisław, Agnieszka Gałkowska. 2008. „Polityka historyczna - o bezużyteczności pojęcia". Państwo i Społeczeństwo 2: 51-58.

Gdula Maciej, Michal Sutowski. 2017. Wstęp. W: Klasy w Polsce, teorie, dyskusje, badania, konteksty, M. Gdula, M. Sutowski (red.), 7-14. Warszawa: Instytut Studiów zaawansowanych.

Gdula Maciej, Przemysław Sadura, Mikołaj Lewicki. 2014. Praktyki kulturowe klasy ludowej. Warszawa: Instytut Studiów zaawansowanych.

Gdula Maciej. 2018. Nowy autorytaryzm. Warszawa: Wydawnictwo Krytyki Politycznej.

Gidron Noam, Bart Bonikowski. Varieties of populism: literature review and research agenda. http://scholar.harvard.edu/files/gidron_bonikowski_populismlitreview_2013.pdf [dostęp: 03.04.2018].

Gundurova Tamara. 2007. „Ressentiment w perspektywie postkolonialnej. Przypadek ukraiński”. Porównania 4.

Hladík Radim. 2009. "Between resentment and forgiveness: public histories in the czech and south african transitions". Teorie Vědy XXXI/2: 113-137.

Hłasko Marek. 1991. Hłasko nieznany. Warszawa: Krajowa Agencja Wydawnicza.

https://oko.press/socjologia-kaczynskiego-prof-spiewak-nikt-mi-mowi-zajmij-sie-lepiejschetyna/ [dostęp: 29.04.2018].

http://www.cbos.pl/PL/trendy/trendy.php?trend [dostęp: 03.04.2018].

http://www.tnsglobal.pl/monitor/ [dostęp: 03.04.2018].

Kącka Katarzyna. 2015. Polityka historyczna: kreatorzy, narzędzia, mechanizmy działania - przykład Polski. W: Narracje pamięci: między polityka a historia, K. Kącka, J. Piechowiak-Lamparska i A. Ratke-Majewska (red.), 59-80. Toruń: Wydawnictwo Naukowe UMK.

Kaltwasser Cristóbal Rovira. 2012. "The ambivalence of populism: threat and corrective for democracy". Democratization 9(2): 184-208.

Kapralski Slawomir. 1989. „Resentyment i zmiana społeczna”. Studia Socjologiczne 2.

Kazin Michael. 1995. The populist persuasion: an American history, Ithaca: Cornell University Press.

Kępiński Antoni. 2013. Psychopatie. Kraków: Wydawnictwo Literackie.

Kowalski Robin. 1996. „Complaints and complaining: Functions, antecedents, and consequences". Psychological Bulletin 119: 179-196.

Krzemiński Ireneusz. 2001. Polacy i Żydzi - wizja wzajemnych stosunków, tożsamość narodowa i antysemityzm. W: Trudne sąsiedztwa $-z$ socjologii konfliktów narodowościowych, A. Jasińska-Kania (red.), 171-200. Warszawa: Wydawnictwo Naukowe Scholar.

Leder Andrzej. 2014. Prześniona Rewolucja. Warszawa: Wydawnictwo Krytyki Politycznej.

Lewicka Maria. 2002. „Daj czy wypracuj? Sześcienny model aktywności”. W: Jednostka i społeczeństwo. Podejście psychologiczne, M. Lewicka, J. Grzelak (red.), 83-102. Gdańsk: Gdańskie Wydawnictwo Psychologiczne.

Linklater Andrew. 2011. The problem of harm in world politics: theoretical investigations. Cambridge: Cambridge University Press. 
Lipowicz Markus. 2010. „Społeczeństwo resentymentu: współczesny proces dezintegracji Niemiec jako efekt (nie)udanej rewolucji kulturowej z lat sześćdziesiątych i siedemdziesiątych". Kultura i Polityka 8: 34-51.

List otwarty do Pana Prezydenta Rzeczpospolitej Polskiej Andrzeja Dudy, Pani Premier Beaty Szydło oraz Pana Marszałka Sejmu Marka Kuchcińskiego pt. „Dość dzielenia i wykluczania, dość dzielenia Polaków”. http:/wwyborcza.pl/1,95891,19370333,dosc-dzielenia-i-wykluczania-dosc-dzielenia-polakow-psychologowie.html [dostęp: 03.04.2018].

Merta Tomasz. 2005. Pamięć i nadzieja, W: Pamięć i odpowiedzialność, R. Kostro, T. Merta (red.), 72-84. Kraków: Ośrodek Myśli Politycznej.

Mellibruda Jerzy. 1995. Pułapka niewybaczonej krzywdy. Warszawa: Instytut Psychologii Zdrowia i Trzeźwości PTP.

Merton Robert K. 1982. Teoria socjologiczna i struktura społeczna. Warszawa PWN.

Mudde Cas. 2004. „The Populist Zeitgeist”. Government and opposition 39(4): 542-563.

Musso Pierre. 2013. Populism and neoliberalism in France and Italy. W: The Changing Faces Of Populism, H. Giusto, D. Kitching, S. Rizzo (eds.), 49-67. Roma: Foundation for European Progressive Studies \& Fondazione Centro per la Riforma dello Stato \& Fondazione Italianieuropei.

Nietzsche Fryderyk. 2003. Z genealogii moralności. Kraków: Zielona Sowa.

Paczocha Janusz. 2018. Raport: Partia w Państwie, bezprecedensowa wymiana kadr w administracji rzadowej i jej legislacyjne podstawy. Warszawa: Forum Obywatelskiego Rozwoju.

Panizza Francisco. 2005. Populism and the mirror of democracy. London: Verso.

Petersen Roger D. 2002. Understanding ethnic violence: fear, hatred, and resentment in twentieth- century Eastern Europe. Cambridge: Cambridge University Press.

Pilat Robert. 2003. Krzywda i Zadośćuczynienie. Warszawa: Wydawnictwo IFiS PAN.

Rancière Jacques. 1995. La mésentente. Paris: Galilée.

Scheler Max. 1977. Resentyment a moralność. Warszawa: Czytelnik.

Skarżyńska Krystyna, Kamil Przybyła, Adrian Dominik Wójcik. 2012. „Grupowa martyrologia: psychologiczne funkcje przekonań o narodowej krzywdzie”. Psychologia społeczna Tom 7, 4(23): 335-352.

Sowa Jan. 2011. Fantomowe ciało Króla. Kraków: Universitas.

Sroka Lukasz Tomasz. 2008. „Rozważania o krzywdzie. Wątki polityki historycznej w publicystyce Adama Michnika". Państwo i Spoleczeństwo 2: 133-140.

Szymków Aleksandra, Bogdan Wojciszke, Wiesław Baryła. 2003. „Psychologiczne funkcje narzekania". Czasopismo Psychologiczne 9/1: 47-64;

Sharafutdinova Gulnaz. 2016. "Managing national ressentiment: morality politics in Putin's Russia". W: Vocabularies of International Relations after the Crisis in Ukraine, A. Makarychev, A. Yatsyk (eds). London: Routledge.

Tischner Józef. 1992. Etyka solidarności i Homo sovieticus. Kraków: Społeczny Instytut Wydawniczy Znak.

Thompson Ewa. 2006. „Sarmatyzm i neokolonializm. O naturze polskich resentymentów”. Europa 46.

Tulibacki Witold (red.). 2003. Krzywda. Zagadnienia teoretyczne i problemy praktyki. Olsztyn: Wyd. Olsztyńskiej Szkoły Wyższej im. Józefa Rusieckiego.

Weryński Piotr. 2017. „Resentyment grupowy jako czynnik warunkujący polską morfostazę strukturalno-kulturową”. Politechnika Śląska: Zeszyty Naukowe. 
Wojciszke Bogdan, Wiesław Baryła. 2005. „Kultura narzekania, czyli o psychologicznych pułapkach ekspresji niezadowolenia". W: Jak Polacy przegrywaja, jak Polacy wygrywaja, M. Drogosz (red.), 32-52. Gdańsk: GWP.

Wojciszke Bogdan, Wiesław Baryła. 2002. „Jak odstrzelić sobie nogę: psychologiczne konsekwencje narzekania". Kolokwia Psychologiczne 10: 213-235.

Żemojtel-Piotrowska Magdalena. 2009. Narzekanie i roszczeniowość a postrzeganie świata społecznego. Gdańsk: Wydawnictwo Uniwersytetu Gdańskiego.

Zinowjew Aleksander. 1987. Homo sovieticus. Warszawa: Wydawnictwo Horyzont.

Mikołaj Rakusa-Suszczewski

THE "POLICY OF HARM" BY THE LAW AND JUSTICE PARTY (PIS)

Summary

Answering the question of why the ruling party in Poland (PiS) maintains such strong support, we refer to various arguments and disciplines, from sociology, discourse analysis, and social psychology to cultural philosophy. We maintain that PiS consistently conducts populist politics, building on strong collective antagonisms and fuelling the social sense of harm. The concept of "harm" has a unique and exceptional power that affects the feelings and the imagination of people. This means that evoking this feeling of harm recalling it proves to be a particularly convenient tool to manage people's consciences and beliefs. In this spirit, we consider how "harm" and its related concepts (resentment) are bound with populist politics, and how the "discourse of harm" is actually present in the recent memory of politics in Poland, and how it can give some social groups "perverse" satisfaction. However, what we see in this semi-conscious tactic, which we describe as the "policy of harm", is long-term destructive consequences.

Keywords: harm, resentment, populism, PiS, memory politics, new authoritarianism 